\title{
En kvinne med nevrofibromatose, infeksjonstegn og blødninger
}

En kvinne med kjent nevrofibromatose ble innlagt for utredning av vedvarende infeksjonstegn. Under oppfølgingen utviklet hun multiple aneurismer, med påfølgende alvorlige og gjentatte blødninger fra flere arterielle kar. Det skulle vise seg at det å finne årsaken til symptomene krevde en omfattende og langvarig utredning.

En kvinne i begynnelsen av 60-årene med kjent nevrofibromatose type 1 ble henvist til lokalsykehuset på grunn av slapphet og lavgradig feber over et par måneder. Pasienten hadde kjent osteoporose, og hun var operert for feokromocytom noen år tidligere. Hun hadde kjente kompresjonsbrudd i columna, ribbensbrudd med dårlig tilheling og hadde nylig hatt et lårhalsbrudd.

Hun var mangeårig røyker med emfysemutvikling i lungene, og hun hadde kjent hypotyreose og psoriasis. Det forelå psykiatrisk komorbiditet med anorexia nervosa gjennom 20 år. Hun veide $45 \mathrm{~kg}$ før innleggelsen.

Nevrofibromatose type 1 er en genetisk tilstand med autosomalt dominant arvegang. Over 240 mutasjoner er beskrevet i tumorsupressorgenet $N F 1$, hvor resultatet er svært nedsatt eller manglende produksjon av proteinet nevrofibromin (1). Klinisk kjennetegnes pasienter med nevrofibromatose av café-au-lait-flekker og godartede nerve- og bindevevssvulster, såkalte nevrofibromer. Det er ellers stor variasjonsbredde i kliniske uttrykk.

Pasientene har blant annet overhyppighet av maligne tumorer. Som hos vår pasient er både feokromocytom og osteoporose beskrevet i tilknytning til tilstanden (ramme 1) (2).

Før endelig diagnose ble stilt, var kvinnen innlagt $i$ lokalsykehuset tre ganger over en periode på et halvt år. Under første innleggelse hadde hun en senkning på $101 \mathrm{~mm}$ (1-28 mm) og et CRP-nivå på $103 \mathrm{mg} / \mathrm{l}(0-5$ $\mathrm{mg} / \mathrm{l}$. Utredningen ble rettet bredt mot infeksjonstilstand, malignitet og revmatisk sykdom. Alle mikrobiologiske prøver var negative. CT thorax/abdomen/bekken avdekket kun en upåfallende ovariecyste. Proteinelektroforese $i$ urin og blod var normal. ANA var negativ og MPO-ANCA viste en grenseverdi på 4,9 IE/ml (0,0-5,0 IE $/ \mathrm{ml})$.

Under den andre innleggelsen hadde hun vedvarende forhøyede inflammasjonsprøver, med CRP-nivå 84-194 mg/l, senkning 86-104 mm og leukocytose med endring fra lett forhøyede monocytter til nøytrofili. Hun hadde mikrocytær hypokrom anemi med gradvis hemoglobinfall fra $10,5 \mathrm{~g} / 100 \mathrm{ml}$ til 7,7 g/100 ml (11,7-15,3 g/100 ml) i løpet av halvannen måned. Gjentatte hemofec-tester var positive på blod. I løpet av fire måneder gikk hun ned i vekt fra $45 \mathrm{~kg}$ til $39 \mathrm{~kg}$.

Utredningen ble nå rettet spesielt mot inflammatoriske og maligne tilstander i fordøyelsessystemet. Samtidig ble spiseforstyrrelsen vurdert til å være en del av bildet, og hun ble henvist til psykiatrisk vurdering.

Gastroskopi viste et hiatushernie og tynntarmsbiopsier normale slimhinner. Det ble gjort ny CT thorax/abdomen/bekken, som ikke forklarte sykdomsbildet.

Pasienten ble etter ny negativ utredning utskrevet til korttidsplass i sykehjem samt til psykiatrisk vurdering med tanke på hennes anorexia nervosa.

Ved ny gransking av CT thorax i arteriefase i ettertid så man at det allerede ved dette tidspunktet forelå noen ørsmå aneurismer. Det er ikke å forvente at så små forandringer blir oppdaget på en generell screeningundersøkelse.

Fra sitt hjem ble hun innlagt for tredje gang på et halvt år, nå med abdominale smerter og akutt fall $i$ hemoglobinnivå til $6,1 \mathrm{~g} / 100 \mathrm{ml}$. $C T$-arteriografi av abdomen viste blødning fra en gren utgående fra a. mesenterica superior. Videre fant man multiple karaneurismer/ pseudoaneurismer i tarmkrøs, rundt ventrikkelen, i leveren, i nyrene og i interkostalarterier, tolket av radiolog som polyarteritis nodosa eller aneurismer forårsaket av septiske embolier. Hun var begynnende sirkulatorisk ustabil med takykardi og blodtrykksfall og fikk transfusjoner med både erytrocyttkonsentrat og plasma.

Pasienten ble overført til gastrokirurgisk avdeling ved regionsykehus, der hun ble hasteoperert med reseksjon av $40 \mathrm{~cm}$ tynntarm. Biopsi fra resektatet viste abscess og hematom. Det var sirkulasjonsforstyrrelser med varierende grad av trombosering med
Arne Kildahl-Andersen

kildahla@yahoo.no

Lungeavdelingen

St. Olavs hospital

Marie Thoresen

Lungeavdelingen

St. Olavs hospital

Ruth Stoklund Thomsen Revmatologisk avdeling St. Olavs hospital

Asbjørn Ødegård

Klinikk for bildediagnostikk St. Olavs hospital 
RAMME 1

(2). Kjente funn og assosierte tilstander

hos pasienten er markert med stjerne

Hud

Café-au-lait-flekker*

Fregner*

Fibromer* (nodulære fibromer, dermale/

pleksiforme nevrofibromer)

Glomustumor

\section{Sentralnervesystem}

Ulike kognitive problemer*

$\emptyset$ kt tendens til tretthet*

Epilepsi

$\emptyset$ ye

Lisch-knuter

Opticusgliom

Skjelett

Osteoporose*

Skoliose* og pseudartrose

Andre assosierte tilstander

Hypertensjon

Vaskulopatier

Interstitiell og bulløs lungesykdom

Generelt økt kreftrisiko

Ondartede bindevevssvulster

Feokromocytom*
Manifestasjoner ved nevrofibromatose type 1

RAMME 2

Differensialdiagnoser til polyarteritis nodosa (3)

\section{Infeksjonstilstander}

Endokarditt/andre sykdommer med

bakteriemi

Mykotisk aneurisme med distal embolise-

ring

Virusinfeksjoner (hepatitt B, hepatitt C, hiv)

Andre tilstander som kan ligne

en vaskulitt (mediumkars-)

Aterosklerose

Embolisk sykdom (myksomer, kolesterolemboli)

Trombotiske tilstander lantifosfolipid-

syndroml

Fibromuskulær dysplasi

Strålefibrose

Ergotisme

Nevrofibromatose

Primær amyloidose

Andre sjeldne tilstander

ANCA-assosierte vaskulitter

Granulomatose med polyangiitt

(tidligere Wegeners syndrom)

Mikroskopisk polyangiitt

Eosinofil granulomatose med polyangiitt

(tidligere Churg-Strauss-syndrom)

\section{Andre vaskulitter}

Henoch-Schönleins purpura (IgA-vaskulitt)

Vaskulitt med kryoglobulinemi

Medikamentindusert vaskulitt

Vaskulitt sekundært til bindevevssykdom

sannsynligvis sekundære betennelsesforandringer, men det var ikke mulig å bekrefte eller avkrefte vaskulitt. Det ble beskrevet betydelige reaktive arrforandringer $i$ karveggene. Dyrkningsprøver tatt peroperativt var negative på bakterier og sopp.

Hun var stabil, men i fortsatt nedsatt allmenntilstand da hun ble ført tilbake til lokalsykehuset i påvente av overnevnte biopsi- og dyrkningssvar, med planer for videre utredning ved revmatolog.

Det finnes mange differensialdiagnoser til vaskulitt og polyarteritis nodosa (ramme 2) (3). Infeksjoner vil kunne gi forandringer som ved vaskulitt eller forandringer som minner om dette. Her var gjentatte blodkulturer og peroperative dyrkningsprøver negative. Infeksjoner med hepatitt B- eller hepatitt C-virus eller parvovirus vil kunne gi et slikt bilde med polyarteritis nodosa. Tromboemboliske tilstander som antifosfolipidsyndrom med arterielle og venøse tromber vil kunne ligne en vaskulitt (3). tanke om tarmiskemi. Det var imidlertid ikke tegn til iskemi ved peroperativ inspeksjon.

Gastrokirurgene ønsket overflytting til revmatologisk avdeling, og pasienten ble overført til lungemedisinsk avdeling i påvente av dette. Valg av lungeavdelingen som oppholdssted var tilfeldig.

Det ble fra revmatologisk hold stilt spørsmål om aneurismedanningene kunne komme av vaskulopati ved nevrofibromatose.

I rekonvalesensperioden etter den andre tarmoperasjonen fikk kvinnen på nytt en stor blødning, denne gang fra den høyre nyren. $P a ̊ ~ C T$-arteriografi fant man blødning subkapsulært, inferiort mot høyre fossa iliaca og høyre flanke. Hun ble tilsett av urolog, som konkluderte med konservativ behandling i form av blodtransfusjon.

Dagen før blødningen var pasienten blitt høyfebril, med produktiv hoste og svært nedsatt allmenntilstand, men hun var ikke intensivtrengende. Det var startet med meropenem mot mulig nosokomial pneumoni. Dyrkning på bakterier og sopp var fortsatt negativ. Revmatologiske prøver viste nå MPO-ANCA på 140 IE/ml 10,0-5,0 IE) $\mathrm{mll}$. For øvrig var det negativt resultat av serologisk prøve for hepatitt $B$ og hepatitt $C$ og negativ lupusantikoagulant. I urinen hadde pasienten hyaline sylindre med celleinklusjoner og kornede sylindre. Urinstiks viste $3+$ og $4+$ på henholdsvis proteiner og erytrocytter.

Det var klar mistanke om vaskulitt med bildefunn som ved polyarteritis nodosa, men også med urinfunn som kunne tyde på glomerulonefritt og en ANCA-assosiert vaskulitt. Nefrolog foreslo nyrebiopsi, men da pasienten allerede hadde blødd fra høyre nyre, var det ikke tilrådelig med biopsi fra den venstre.

Pasienten var sengeliggende og i svært nedsatt allmenntilstand. CRP-nivået steg under antibiotikabehandling, og det var ikke mulig med ytterligere vaskulittdiagnostikk.

På vital indikasjon og etter drøfting med revmatolog ble det igangsatt høydosebehandling med steroider (Solu-Medrol $500 \mathrm{mg}$ daglig over tre dager) og videre behandling med prednisolon $20 \mathrm{mg}$ daglig, det tilsvarte $0,5 \mathrm{mg} / \mathrm{kg}$. Senkningen var på det tidspunktet $>140 \mathrm{~mm}$ og CRP-nivået var steget til $318 \mathrm{mg} / \mathrm{l}$. Fire dager ut $i$ behandlingen var allmenntilstanden bedre. Pasienten var afebril, senkning og CRP-nivå var henholdsvis $18 \mathrm{~mm}$ og $34 \mathrm{mg} / \mathrm{l}$.

Etter initial behandling med steroider fikk hun cyklofosfamid intravenøst hver tredje uke og prednisolon, der dosen ble trappet ned til $10 \mathrm{mg}$ daglig. Hun utviklet høyt blod- 
trykk (160-175/90-105 mm Hg) i forløpet, og det ble tidlig startet opp med amlodipin $5 \mathrm{mg}$ og kandesartan $8 \mathrm{mg}$. Blodtrykket lot seg behandle med dette, og proteinurien gikk tilbake.

Pasienten, som hadde vært helt sengeliggende og i dårlig allmenntilstand, ble oppegående på avdelingen i løpet av et par uker. Hun ble utskrevet til videre rehabilitering og oppfølging ved revmatologisk poliklinikk for videre behandling med cyklofosfamid. Etter et halvt år hadde hun gått opp $11 \mathrm{~kg}$, og ny CT thorax/abdomen/bekken var uten tegn til aktiv vaskulitt.

\section{Diskusjon}

Pasienten hadde bildefunn forenlig med polyarteritis nodosa. Dette er en sjeldent forekommende tilstand, med estimert årlig insidens på 4,4 til 9,7 per million (7). Sykdommens etiologi er ikke sikkert kjent. Den er kjennetegnet av affeksjon av mellomstore arterier, hvor arterioler, kapillærer og vener spares. Alle organer kan i praksis affiseres. Pasientene kan ved nyreaffeksjon ha moderat hematuri og proteinuri, men tilstanden gir ikke røde cellesylindre og glomerulonefritt. Nodosa henspiller på danningen av aneurismer, som kan palperes som knuter over blodkarene.

Som regel blir diagnosen stilt ut fra biops med funn av transmural nekrotiserende inflammasjon i mellomstore arterier. Alternativet til biopsi er typiske angiografifunn av multiple aneurismer og stenoser. CT- og MRundersøkelse har i stor grad erstattet konvensjonell angiografi, og CT thorax/abdomen av vår pasient viste multiple karaneurismer og pseudoaneurismer i tarmkrøs, rundt ventrikkel, i lever, nyrer og interkostalarterier. Hun fikk standard behandling for tilstanden med steroider og cyklofosfamid,

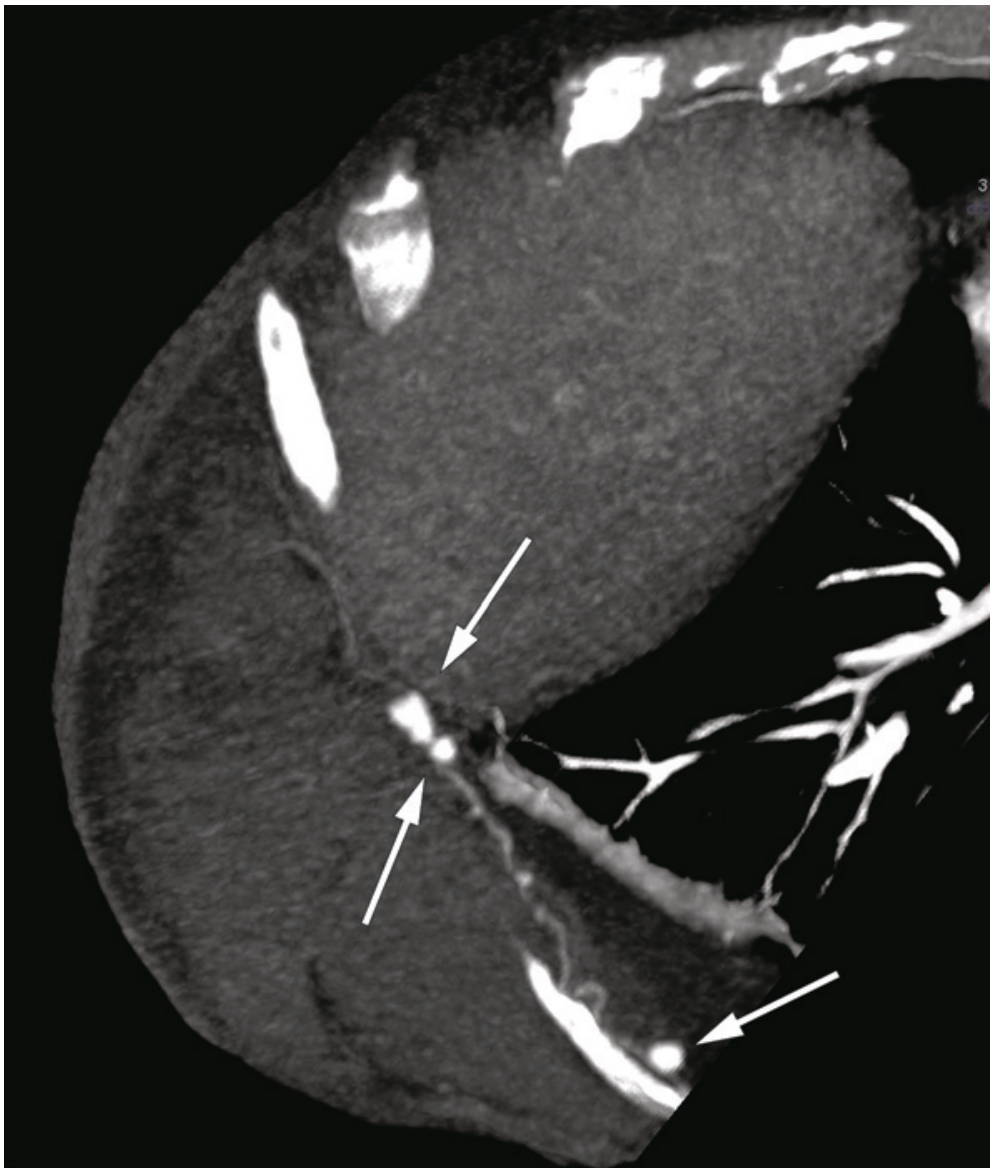

Figur 1 CT-fremstilling av 9. interkostalarterie på høyre side med flere aneurismer og blødning i thoraxveggen. Aneurismene er markert med hvite piler

Pasienten hadde også funn som kunne tale imot denne diagnosen. Hun hadde positiv MPO-ANCA, noe som ikke passer med polyarteritis nodosa. ANCA-assosierte vaskulitter regnes å omfatte granulomatose med polyangiitt (tidligere Wegeners granulomatose), Churg-Strauss-vaskulitt, mikroskopisk polyangiitt og nyrebegrensende vaskulitt. MPO-ANCA er imidlertid uspesifikk og har vært beskrevet som positiv ved en rekke
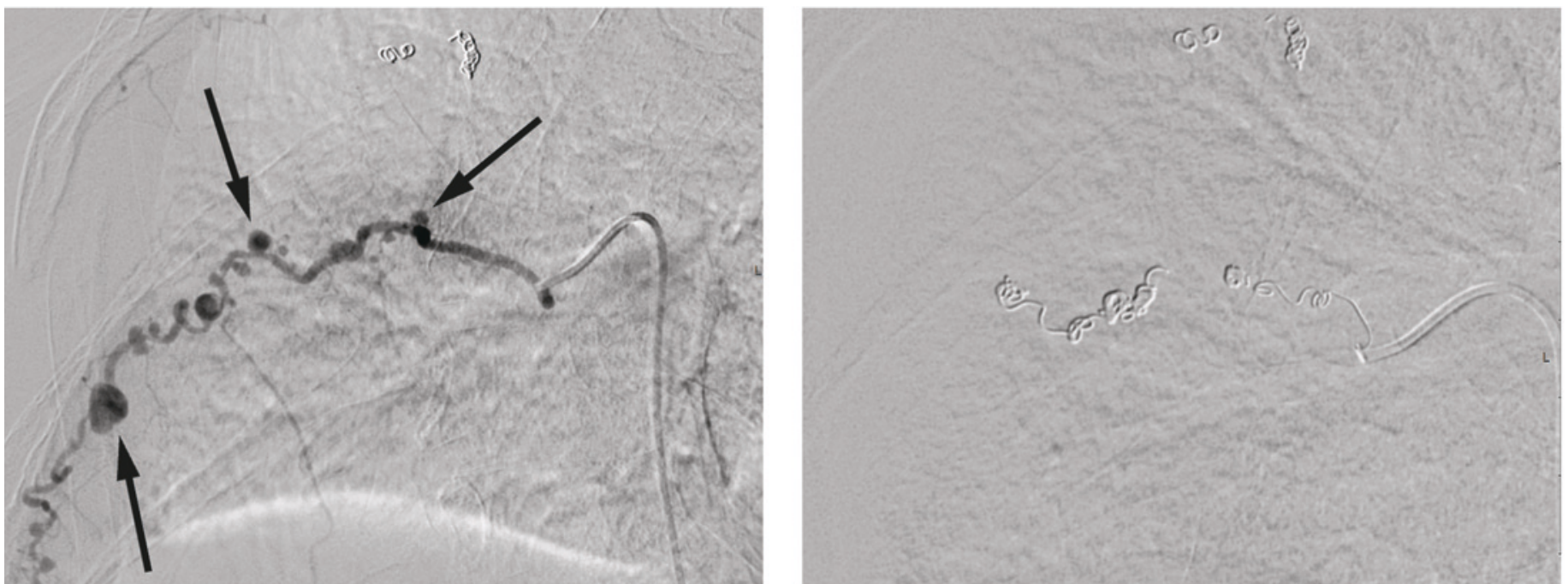

Figur 2 Endovaskulær intervensjon med coiling. 8. interkostalarterie er alt behandlet. De største aneurismene er markert med svarte piler. al Med åpen 9. interkostalarterie. b) Etter behandling med coiling 
inflammatoriske tilstander. Vår pasient hadde tegn på glomerulonefritt med hematuri, proteinuri og sylindre med celleinklusjoner; funn som kunne trekke mer i retning av mikroskopisk polyangiitt, der MPO-ANCA er positiv hos over halvparten. Samtidig er det beskrevet vaskulittformer der positiv MPO-ANCA er funnet hos pasienter med kliniske funn mest forenlig med polyarteritis nodosa $(8,9)$.

Klassifiseringen av vaskulitter har vært gjenstand for mye debatt, da kriteriene har vært overlappende og motsigelsesfulle. Kriteriene til American College of Rheumatology (ACR) fra 1990 inkluderte verken mikroskopisk polyangiitt eller diagnostikk med vekt på ANCA, som den gang ikke var i utbredt bruk.

Ved Chapel Hill Consensus Conference (CHCC) i 1994 ble vaskulittene definert ut fra størrelsene på de affiserte blodkarene. Man anerkjente at histologiske funn ikke alltid foreligger, slik at man vil måtte støtte seg til surrogatmarkører for den enkelte vaskulittsykdom. CHCC-definisjonene ble oppdatert i 2012 (10). Det presiseres at en vaskulitt i mellomstore eller store blodkar også kan affisere små arterier. Motsatt kan en typisk småkarsvaskulitt som mikroskopisk polyangiitt også affisere mellomstore arterier. Nytt fra 2012 er at man implementerer gruppen ANCA-assosierte vaskulitter.

I 2007 kom det forslag på surrogatmarkører og bruk av ANCA i en algoritme - EMA-algoritmen (The European Medicines Agency) - i den hensikt å klassifisere ANCA-assosierte vaskulitter og polyarteritis nodosa (11). Ennå er ikke klassifisering av ANCA-assosierte vaskulitter validert, derfor er dette kontroversielt.

Dessverre lot det seg ikke gjøre å få nyrebiopsi av vår pasient, fordi hun nylig hadde hatt blødning fra høyre nyre. Med utgangspunkt i EMA-algoritmen for klassifisering av ANCA-assosierte vaskulitter står man uten biopsi, men har positiv MPO-ANCA og surrogatmarkører med urinfunn som kornede sylindre, hyaline sylindre med celleinklusjoner, proteinuri og hematuri. Dette skulle tale for en glomerulonefritt og en mikroskopisk polyangiitt. Men selv da hun var på sitt sykeste så vi ingen kreatininstigning, noe man kanskje ville forvente ved en eventuell nekrotiserende glomerulonefritt. Sett i sammenheng med at pasienten blødde fra den ene nyren, var heller ikke urinfunnene så spesifikke. Distribusjonen av affiserte blodkar var klinisk som man kunne forvente ved polyarteritis nodosa, som var diagnosen hun fikk. Behandlingen er i utgangspunktet den samme ved disse to diagnosene, som tidligere ble klassifisert som én.

Selv om det er uvanlig, er affeksjon av interkostalarterier beskrevet tidligere i sammenheng med polyarteritis nodosa $(12,13)$.
Karskade med aneurismedanning i interkostalarterier er som nevnt tidligere beskrevet hos nevrofibromatosepasienter. Hvorfor pasienter med nevrofibromatose utvikler forandringer i blodkarene med aneurismedanning, er ikke fullt ut forstått.

Modeller med heterozygote NF1-mutasjoner hos mus har vist økt vaskulær inflammasjon i skadede kar sammenlignet med kar hos genetisk normale mus (14). Genproduktet nevrofibromin virker hemmende på inflammasjon, intimaproliferasjon og til sist aneurismedanning. Hos pasienter med nevrofibromatose kan man tenke seg at enhver skade på blodkar gir en kraftigere inflammasjon og raskere utvikling av aneurismer med eventuelt ruptur sammenlignet med det som skjer hos friske. En vaskulitt vil kunne representere en slik karskade.

\section{Oppsummering}

Utredning av vaskulitter kan være utfordrende - både med tanke på differensialdiagnoser og endelig typebestemmelse av dem. Vi har beskrevet en pasient med kjent nevrofibromatose som ble behandlet for vaskulitt. Utredningen tok tid, og pasienten hadde flere alvorlige blødninger, med behov for transfusjon og kirurgiske inngrep, før diagnosen ble satt. Allmenntilstanden ble gradvis svekket inntil hun var helt sengeliggende. CT-undersøkelse avdekket multiple aneurismer, og hun blødde fra tre av disse, beliggende i mesenteriet, interkostalarterier og nyrearterier.

Karaneurismer er beskrevet ved nevrofibromatose, men ikke i en slik utstrekning og med så rask utvikling. Det kan likevel ikke utelukkes at pasientens nevrofibromatose har hatt noe å si for distribusjonen av affiserte kar og sykdomsprogredieringen. Bildemessig var hennes vaskulitt mest forenlig med polyarteritis nodosa. Hun hadde samtidig tegn på glomerulonefritt, med positiv MPO-ANCA, som man kan se ved mikroskopisk polyangiitt. Kombinasjonen er svært sjelden. Patogenesen for hver tilstand sett hver for seg er ikke fullt ut kartlagt, heller ikke mekanismen for hvordan de påvirker hverandre hos en og samme pasient.

Pasienten ble raskt mye bedre etter behandlingen med Solu-Medrol, og nå, ett år etter, er hun fortsatt oppegående og i god allmenntilstand.

Pasienten har gitt samtykke til at artikkelen blir publisert.

\section{Arne Kildahl-Andersen (f. 1976)}

er lege i spesialisering i lungemedisin.

Forfatter har fylt ut ICMJE-skjemaet og oppgir

ingen interessekonflikter.

\section{Marie Thoresen (f. 1979)}

er konstituert overlege i lungemedisin. Forfatter har fylt ut ICMJE-skjemaet og oppgir ingen interessekonflikter.

\section{Ruth Stoklund Thomsen (f. 1967)}

er overlege i revmatologi.

Forfatter har fylt ut ICMJE-skjemaet og oppgir ingen interessekonflikter.

\section{Asbjørn Ødegård (f. 1961)}

er overlege i radiologi.

Forfatter har fylt ut ICMJE-skjemaet og oppgir ingen interessekonflikter.

\section{Litteratur}

1. Rasmussen SA, Friedman JM. NF1 gene and neurofibromatosis 1. Am J Epidemiol 2000: 151: 33-40.

2. Gutmann DH, Aylsworth A, Carey JC et al. The diagnostic evaluation and multidisciplinary management of neurofibromatosis 1 and neurofibromatosis 2. JAMA 1997: 278: 51-7.

3. Staud R, Yancey WB Jr, Williams RC Jr. «Vasculitis look-alike» clinical syndromes. J Clin Rheumatol 1996; 2: 203-8

4. Oderich GS Sullivan TM, Bower TC et al. Vascular abnormalities in patients with neurofibromatosis syndrome type I: clinical spectrum, management, and results. J Vasc Surg 2007; 46: 475-84.

5. Misao T, Yoshikawa T, Aoe M et al. Recurrent rupture of intercostal artery aneurysms in neurofibromatosis type 1. Gen Thorac Cardiovasc Surg 2012 60: $179-82$

6. Arai K, Sanada J, Kurozumi A et al. Spontaneous hemothorax in neurofibromatosis treated with percutaneous embolization. Cardiovasc Intervent Radiol 2007; 30: 477-9.

7. Watts RA, Lane SE, Scott DG et al. Epidemiology of vasculitis in Europe. Ann Rheum Dis 2001; 60: $1156-7$.

8. Tanaka M, Matsuo K, Nakamura $\mathrm{H}$ et al. Two cases of classical polyarteritis nodosa associated with MPO-ANCA. Nihon Jinzo Gakkai Shi 2006; 48: $371-6$

9. Yokoi Y, Nakamura I, Kaneko T et al. Pancreatic mass as an initial manifestation of polyarteritis nodosa: a case report and review of the literature. World J Gastroenterol 2015; 21: 1014-9.

10. Jennette JC, Falk RJ, Bacon PA et al. 2012 revised International Chapel Hill Consensus Conference Nomenclature of Vasculitides. Arthritis Rheum 2013; 65: 1-11.

11. Watts R, Lane S, Hanslik T et al. Development and validation of a consensus methodology for the classification of the ANCA-associated vasculitides and polyarteritis nodosa for epidemiological studies. Ann Rheum Dis 2007; 66: 222-7.

12. Koçak H, Cakar N, Hekimoglu B et al. The coexistence of familial Mediterranean fever and polyarteritis nodosa; report of a case. Pediatr Nephrol 1996; 10: 631-3.

13. Fisher RG, Graham DY, Granmayeh M et al. Polyarteritis nodosa and hepatitis-B surface antigen: role of angiography in diagnosis. AJR Am J Roentgenol 1977; 129: 77-81.

14. Lasater EA, Li F, Bessler WK et al. Genetic and cellular evidence of vascular inflammation in neurofibromin-deficient mice and humans. J Clin Invest 2010: 120: 859-70. 